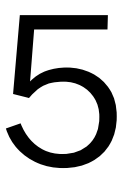

\title{
Traditional places in conflict and their historic context: Ritidian, Guam
}

\author{
Boyd Dixon, Andrea Jalandoni and Maria Kottermair
}

\section{Introduction}

The term 'traditional places in conflict' in the title does not imply that pre-Contact Period village sites such as Ritidian on the island of Guam in the Mariana Islands of Micronesia (Figure 5.1) were deliberately constructed to be settings of defence or animosity. Rather, non-indigenous participant observers recorded traditional conflict before the late seventeenth century in contested spaces between indigenous Chamorro village sites, and often quite literally 'on the beach' (Flexner 2014:49). Some traditional villages on Guam may then have assumed a role in conflict when Spanish, American and Japanese forces imposed their will upon the resident population.

When the first Austronesian voyagers reached the shores of Ritidian c. 1500 BCE, the mean sea level was approximately $1.8 \mathrm{~m}$ higher than present (Dickinson 2000, 2001), towards the end of the Holocene Epoch. The high sea level then began to drop from c. 1100 BCE until around 100 CE when it reached near present-day levels. The first inhabitants at Ritidian were therefore restricted to a narrow beach area, but the gradually retreating sea exposed more beach to inhabit by the Latte Period (1000-1521 CE), allowing for more native vegetation and farming areas, and encouraging reef and sand dune development that supported marine food abundance and protection from tidal surges (Carson 2010, 2012, 2014). Today, latte structures at Ritidian and across the Mariana Islands are one of the most distinguishable aspects of Chamorro culture, a symbol with which the local people identify themselves even today. The latte are composed of two parts, stone columns ( haligi) and caps or tops (tasa). The stone pillars and their caps held up an A-framed structure probably made of wood and thatch. Archaeological evidence at Ritidian and early historic archival documents suggest the latte buildings served various related functions such as family housing, canoe and domestic implement storage, household food production, and ancestor veneration (Bayman et al. 2010; Dixon et al. 2006; Reinman 1977; Thompson 1940).

Bayman et al. (2012) investigated two adjacent latte sets, located on the west side of Ritidian, and demonstrated different but interrelated domestic activities during the early Contact Period (1521-1668 CE). Each latte building had its own economic specialty and both were probably gender-specific. Nearby, there are four known caves at the cliff line with multicoloured pictograms. Not all the figures are identifiable, although there are some anatomically correct anthropomorphic images in black, red and white pigment. While none of the pictograms have yet been precisely dated, the black and red images are suspected to be Pre-Latte in date, while the white images are suspected to date to the Latte Period (Carson 2017). 


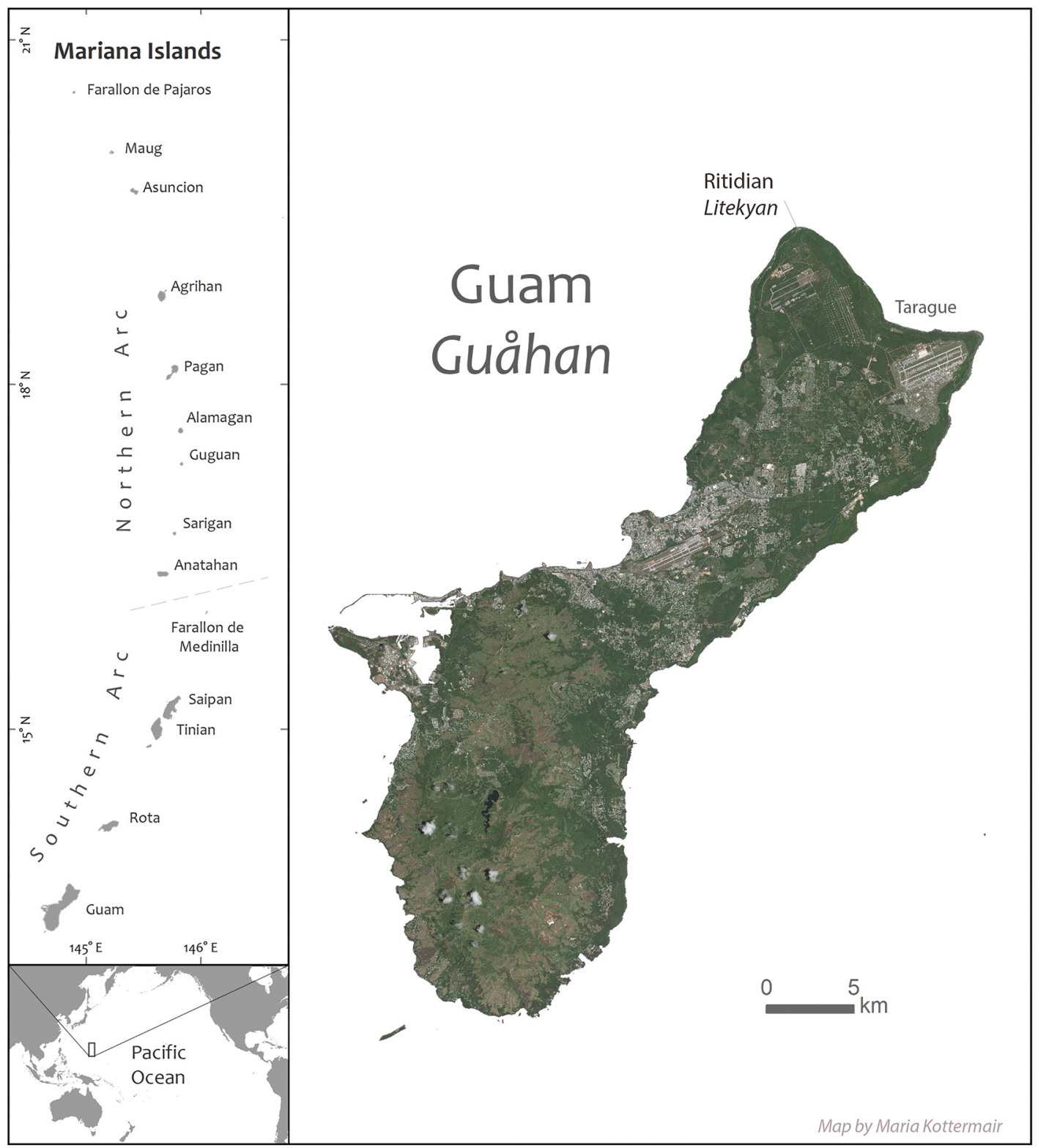

Figure 5.1. Guam and Ritidian with the Northern Mariana Islands.

Source: Maria Kottermair.

The site of Ritidian is also historically significant for the wealth of archival documentation of the early interaction between the Spanish clergy and the Chamorro residents. Archaeological evidence of a stone church or priest residence in Ritidian has recently uncovered valuable information about the tenuous early Spanish Colonial Period (Jalandoni 2011). In 1674 CE, construction of a church dedicated to St Francis Xavier began at Ritidian, and was completed the following year in $1675 \mathrm{CE}$ by the Jesuits, presumably using native labour and materials. In December $1675 \mathrm{CE}$, Brother Diaz was murdered in an altercation with the urritaos (young native men) over a cultural difference in premarital behaviour, after Brother Diaz and an assistant tried to burn the guma urritao or single men's house (Farrell 2011). The murder of Brother Diaz then led the Chamorro to burn the church, residences and schools, as well as abandoning the village to take refuge in Rota. 
While the village was abandoned, members of the rival village of Tarague burned the remains of Ritidian, cut down food-bearing trees and destroyed crops. The Chamorro eventually returned to Ritidian by $1681 \mathrm{CE}$ and a stone church dedicated to San Miguel was built in nearby Jinapsan to service several of the surrounding villages. That church and priest residence were subsequently burned down and rebuilt twice. In 1684 CE, the resident priest, Fr Angelis, was killed at Ritidian during a Chamorro revolt. The area of Ritidian was again abandoned for almost a century when the Spaniards forced the Chamorro to relocate to southern Guam (Jalandoni 2011).

\section{Pre-Contact conflict: 1500 BCE-1521 CE}

The traditional causes of pre-Contact conflict on Guam and at Ritidian are many, likely rooted in the growth of relatively small early Pre-Latte Period Chamorro populations on islands of finite resources, in a fluctuating global climate. Archaeological evidence of initial settlement of the Mariana archipelago c. 1500 BCE is relatively sparse and not clustered within individual islands, suggesting that maritime settlers of the archipelago targeted a wide range of natural habitats to maximise survival upon landing (Dixon and Dega, In press). These settings included inland estuaries and marshes, cliff lines with caves, native forests and soils, and beach dunes with shallow lagoons and offshore reefs. Recent DNA research and similarities in material culture with Southeast Asia suggest multiple origins to the Marianas, which probably originated along a cultural corridor from the Philippines to Sulawesi and island Melanesia beginning between 1500-1100 BCE (Vilar et al. 2016). This settlement strategy of 'social distancing', targeting various habitats upon arrival, may therefore have been a long-practised mechanism to avoid initial conflict between various seafaring families and clans of uncertain lineage.

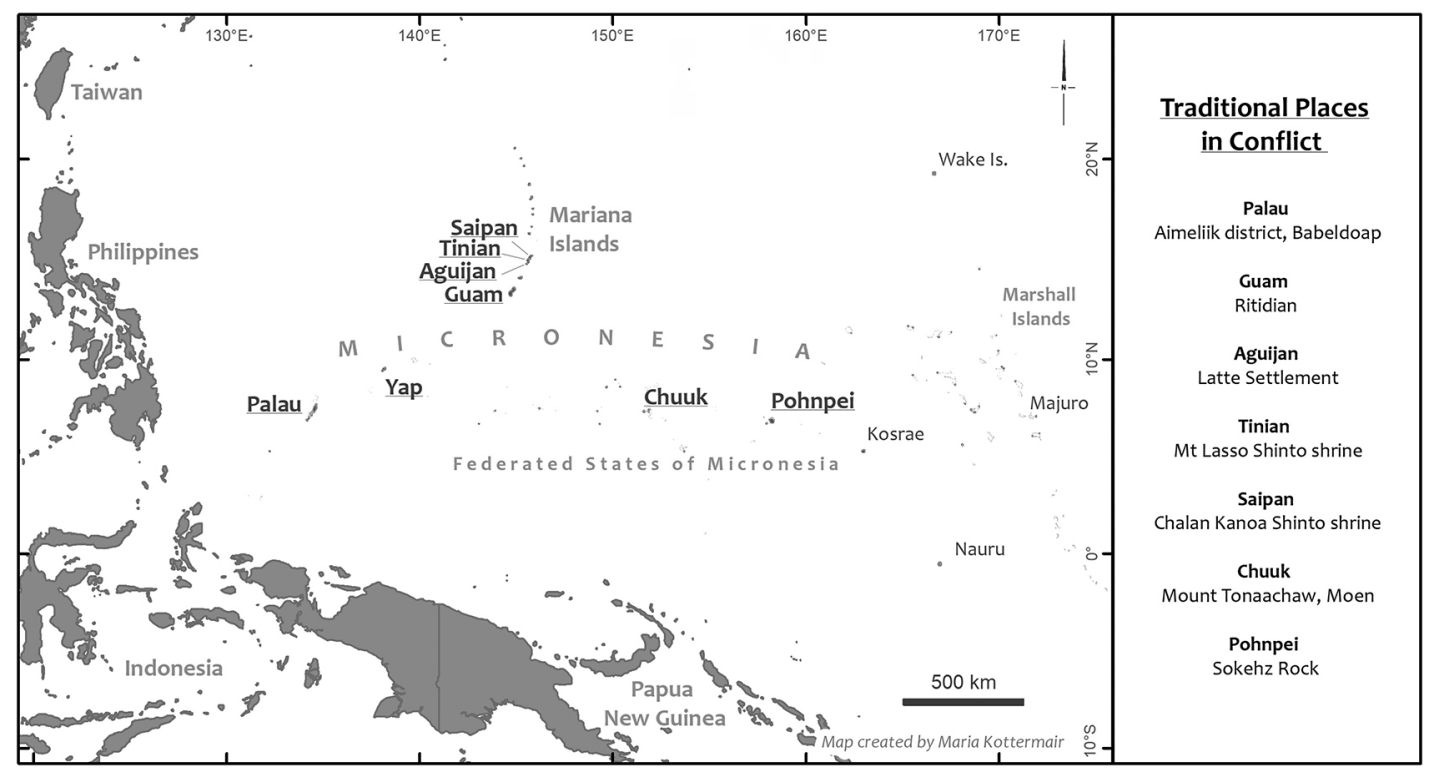

Figure 5.2. Selected traditional places in conflict across Micronesia.

Source: Maria Kottermair.

By the Latte Period, it can be assumed that some altercations accompanied the gradual infilling of early island environments, but there is no evidence of pre-Contact fortifications or defensive site locations on Guam such as existed elsewhere across Micronesia (Figure 5.2) until well after European contact. The symbolic projection of coercion, force and violence has been surmised at Palauan crowns and ring-ditches from 600 BCE to 1000 CE (Liston and Tuggle 2006), and at Chuukese hill forts c. 1300 CE (Nunn 2007; Rainbird 2004). Historic-era conflict is associated with the Chamorro island stronghold of Aguijan in 1695 CE during the Spanish Contact Period 
(Butler 1992), at Sokehz Rock on Pohnpei during the German administration and rebellion in 1911 CE (Hezel 2016), and during the World War II American invasion of 1944 CE at the traditional Japanese Shinto shrines of Mt Lasso on Tinian (Farrell 2012) and Chalan Kanoa in Saipan (Russell 1984). Ritidian and all these sites, whether pre-Contact, historic or early twentieth century, were also at times a place of elite ritual, reverence, habitation, burial and/or cultivation claimed by native or non-indigenous peoples (cf. Liston 2014).

Traditional warfare and conflict was relatively common on Guam in the contact era, but left little direct evidence apart from bone spear points and shaped sling stones (Dixon 2011).

The Latte Period (between 1000 and 1668 CE) is distinguished from the preceding Pre-Latte Period (between $1500 \mathrm{BCE}$ and $1000 \mathrm{CE}$ ) (Carson 2014) by a greater number of sling stones in archaeological sites, consistent with pre-contact conflict (Hornbostel 1924-25; Morgan 1988; York and York 2014). Unlike the massive terraces and hilltop crowns the early Palauans built for several reasons including their defence (Liston 2009), Latte Period settlements were built with little apparent concern for defence (Russell 1998). Many latte sets or house foundations are found on ridge tops in the interior of southern Guam (Dixon and Gilda 2011), but these sites likely occupied settings connected to ancient footpaths from which the occupants could farm arable soils and wetlands and gather native forest resources.

Artefacts of Latte Period warfare are relatively easy to identify in the archaeological record since there were no large animals to hunt in the Mariana Islands, and these weapons were mentioned respectfully by early Spanish visitors and settlers to Guam. Sling stones of baked clay, limestone, mudstone and basalt, such as those found at Pagat Village (Craib 1986), were deadly at close range, and were an effective way to keep the enemy at a distance. While sling stones are commonly found around most coastal Latte Period villages, including at Ritidian Point (Thompson 1932:49), clusters of them denoting possible manufacture for broader distribution are mostly restricted to southern Guam where raw materials occur naturally in the cliffs and uplands above coastal villages. Sling stones were also modified for use as net sinker weights, gaming pieces, amulets or ornaments, and as burial goods (York and York 2014).

When combat or the element of surprise was called for, fire-hardened or barbed human-shinbone tipped spears such as those found at Ritidian (Dixon and Jalandoni 2019) could dispatch many a warrior who returned home to find his wounds infected from poison on the spear tips. Magellan's chronicler Antonio Pigafetta noted that:

When our people wounded any of the islanders with their arrows, (of which weapon they had no conception), and chanced to pierce them through, the unfortunate sufferers endeavoured to draw out these arrows from their bodies, now by one end, now by another; after which they looked at them with astonishment, and sometimes died of their wounds. (Pigafetta in Lévesque 1992:214)

Indeed, what is believed to be the first of the 'Ladrones' or Chamorro warriors ever depicted c. $1590 \mathrm{CE}$ was naked and without body armour or tattoos (Figure 5.3) in the Boxer Codex (Dasmarinas 1595).

It is probably safe to assume that by the time late Latte Period populations had increased, so had the demand for firewood, construction materials, forest fruits, native herbs and agriculturally produced foods (Dixon and Schaefer 2014). Changes in late pre-Contact settlement, from a primarily coastal orientation to a more inland focus, are noted across much of the Pacific between roughly 1300 and $1800 \mathrm{CE}$ (Nunn et al. 2007), in many cases interpreted as a response to the Little Ice Age and its effects on sea level, temperature and rainfall. In the Marianas archipelago, however, it would be difficult to portray these climatic changes as related to societal upheaval and conflict, since existing coastal settlements appeared to grow in size at much the same time as substantial new settlements appeared in the interior of the larger islands (Dixon et al. 2011a). 


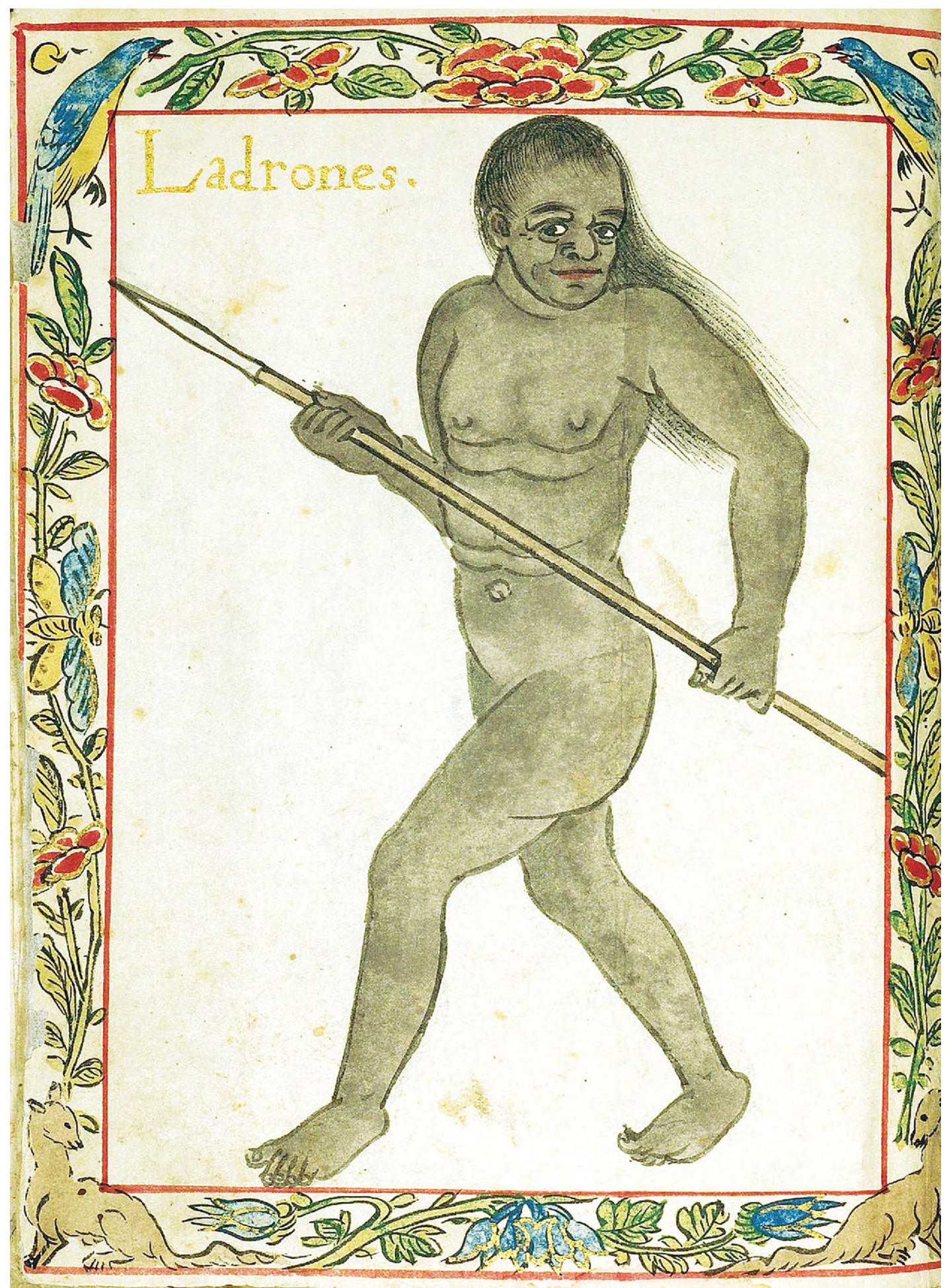

Figure 5.3. First depiction of a Chamorro warrior, c. 1590-1591 CE.

Source: Boxer Codex, attributed to Gomez Perez Dasmarinas (Dasmarinas 1595). 
When assessing these possible changes after the arrival of Magellan in $1521 \mathrm{CE}$, the scenario is differently recorded between early historic accounts and later archival documents. One interpretation suggests that interactions between aliens and natives remained superficial and transient on the whole until the arrival of the Jesuit mission' (Underwood 1973:12) and 'no evidence exists that any extensive decline took place among the Chamorro either as a result of the introduction of diseases or in armed conflict, until a later period of history' (Underwood 1973:13). An opposing perspective maintains that 'it is difficult to believe that the Marianas population suddenly began to decline when the missionaries arrived in 1668' (Shell 1999:293), since 'there can be no serious doubt that the known epidemics, and lesser ones that may not have been recognised as such, took a disproportionate toll of infants, children and the frail and elderly' (Shell 1999:303).

The demographic effect of combat-related casualties on the pre-Contact population in the Mariana Islands is likewise not easy to assess. In one late Latte to Contact Period (1400$1668 \mathrm{CE}$ ) village on Saipan, with a skeletal MNI (minimum number of individuals) population of 93 individuals, a single barbed human bone spear point was encountered in a disturbed burial context containing one child and two adults at the village site of Afetna (Dixon et al. 2019), but the artefact's precise association was impossible to determine. In the late Latte Period village site at Anaguan in Garapan (Dega et al. 2017) on Saipan, with a skeletal population of over $416 \mathrm{MNI}$, one male was encountered with a single sling stone imbedded in his ribs, one male was found with a cache of 15 sling stones, and one male had over 150 sling stones at his side. Nine human bone spear points were also found in non-burial contexts.

At the Naton Beach Pre-Latte and Latte Period village site on Guam (DeFant 2009), with a skeletal population of $370 \mathrm{MNI}$, 'there was no evidence of death from warfare' (Walth 2016:i). One sling stone was found as a grave good in a Pre-Latte burial. Six were found with Latte Period adult males and females, and five were found with Latte Period subadults of indeterminable gender. Only two human bone spear points were encountered in Latte Period non-burial contexts. While these burial samples vary considerably in size and combat-related grave good volumes, they leave the impression that only a small percentage of the male population was ever directly involved in conflict.

\section{Contact Period conflict: 1521-1668 CE}

Historical accounts from the period of European contact with Guam, spanning the early sixteenth to late seventeenth centuries, document sporadic bellicose interactions with Chamorro, beginning with the first visit to the island by Ferdinand Magellan in $1521 \mathrm{CE}$. After settlement of the island in 1668 CE by Spanish clergy and militia or soldiers from the Philippines and Mexico, initial curiosity and goodwill were transformed into a largely confrontational relationship within a decade of native resistance to Spanish demands to abandon traditional culture and adopt imposed beliefs and behaviour. Small churches built in existing Chamorro villages at desirable beach settings often with protective cliffs (Figure 5.4) often became flashpoints of conflict by the 1680s CE, such as at Ritidian. Intervillage conflict before Spanish contact during the Latte Period was not unknown but is not believed to have risen above the level of clan or family feuds (Hezel 2015), rarely resulting in more than a few casualties.

A manuscript by Fray Peter Coomans written around 1672-1673 noted:

Then, if envy would make them want to burn a house from a distance, they would stuff the perforated side of it [the sling] with tow burning with a very ferocious fire, which, with a swift movement became a flame, and sail away to seek shelter in enemy houses. (Coomans, in Lévesque 1995:99) 


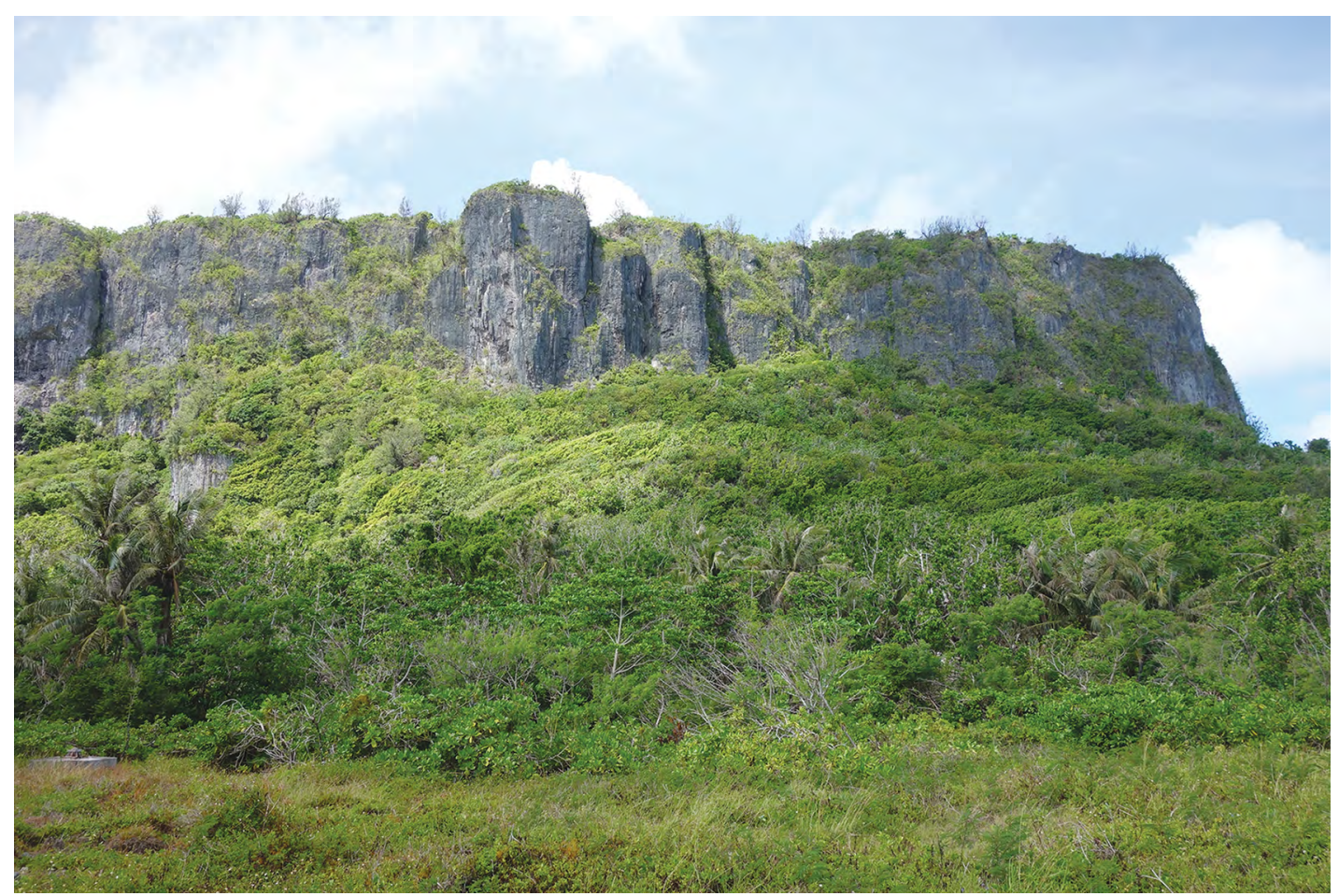

Figure 5.4. Ritidian Point to the south-east from the Guam National Wildlife Refuge.

Source: Mike Carson.

As protection from sling stones, he observed:

Their defensive weapons are hardly more than palm mats, which they place like a hat on their heads by way of a helmet. They also used another [mat] which they tie around their chest by way of a breast-plate, leaving the rest of their body naked; this way they can more easily shoot their sling, or throw spears. (Coomans, in Lévesque 1995:99)

The simple but effective weapons used by Chamorro during conflict with the Spaniards and their militia were best suited to a style of warfare that involved small groups of warriors engaging briefly and often at some distance (Dixon 2011), with the goal being to inflict some damage to the enemy perhaps in an ambush, but then withdraw to fight another day. The goal seemed to be to take an aggressive stance if some insult could not be ignored, but then agree to terms that everyone could live with. In 1602 CE, Fray Juan Pobre was told by his informant Sancho on Rota that:

When one kills another, if they are from the same town he absents himself from that town to go to another island so that the relatives will not kill him. He remains absent until from the killer's house or from that of his father or mother they take one or two palms of tortoise [shells] which is the thing that is most valued among them and with some big fish and rice they pay the father or mother or wife of the deceased for the death. Once this has been done, they send word to the exile and he can come freely and walk about fearlessly through his town and that is their form of justice. (Pobre, in Lévesque 1992:182)

Combat training did appear to be a necessary part of every Chamorro warrior's life when charged with defending his village and its elders. Fray Juan Pobre's informant Sancho noted that:

The young men usually show off their strength in front of these chiefs and they wrestle arms open and make each other tumble. ... and thus they test their strength or sometimes they move apart from each other and, although in jest they usually act as earnestly as in fencing. 
They take some spears at 10 or 12 paces, one throws at the other and although they are skilful at hitting correctly, they are more so in avoiding being hit, and many times they grab the spear in the air. (Pobre, in Lévesque 1992:181)

No mention is made, however, that any Chamorro village maintained a standing army or militia, nor were there obvious officers or insignias of rank during combat (Dixon 2011), as the Spanish would easily have recognised from their own military training.

Possible evidence of combat-related wounds has been suggested in Contact Period (1521$1668 \mathrm{CE})$ skeletal populations in the Mariana Islands, but such individuals were rarely buried with securely dated non-native Chamorro (Dixon et al. 2017). Acts of violence and Chamorro deaths were recorded during the early visits of Magellan and Legaspi (Farrell 2011), although actual contact was rather limited between Europeans and Chamorro since most close encounters occurred on shore during very short visits to replenish fresh food and water and conduct limited trade.

On the active volcanic island of Pagan, north of Saipan, bird-leg bone spearheads of Phasionidae sp., a Carnelian bead, Ming Dynasty blue and white porcelain sherds, and metal artefact fragments with wooden attachments were found in sealed Latte Period contexts with charcoal radiocarbon dates of $1325 \pm 90 \mathrm{BP}, 1495 \pm 115 \mathrm{BP}$ and $1665 \pm 95 \mathrm{BP}$ (Egami and Saito 1973:208), 'suggesting to the authors pre-Magallanes [Magellan] contact with Iron Age Southeast Asia, and perhaps an attempt to introduce chicken or pheasant' (Dixon et al. 2017:201). No burial evidence of conflict was noted.

\section{Spanish colonial conflict: $1668-1898$ CE}

Events after the Spanish settled in the principal village of Hagåtña in 1668 CE eventually led to open conflict between soldiers and Chamorro warriors at more than one location. According to Hezel and Driver (1988:137), 'twelve priests, perhaps 20 of their lay helpers, and an uncounted number of soldiers and Chamorro warriors died in the periodic skirmishes that occurred over a 17-year period'. This violence eventually culminated in la Reducción between roughly 16841720 CE (Jalandoni 2011), when most Mariana and northern Guam populations were forcibly removed to six southern villages with a church and small Jesuit presence to enforce order and acculturation. As defined by Driver on Guam, la Reducción was:

the method employed by the Spanish ecclesiastical and military authorities to convert or Christianize the indigenous inhabitants of an area and bring them from what they considered rustic living conditions into more highly organized communities that were centred around a church or mission. (Driver, in Jalandoni and Peterson 2013)

La Reducción was not well received by Chamorro residents of the villages being forced from their ancestral homes and the burial places of their kin, so their response was not the submission the Jesuits had hoped for, as later described by Velarde in 1759 CE:

Another reason is that these natives love their independence so strongly that they tolerate nothing that restricts their freedom. The yoke of subjection is very hard on their pride and, though they all possess strange ways, the subjection causes some in desperation to take their own lives by hanging themselves. Some women practice sterilization or throw their new born babies into the sea. They believe that it is better to die than to live and experience true sadness or hardship. (Velarde 1987:16) 
Ritidian, one of several well-populated villages situated on the north-western coast of Guam with a small church later known as the Casa Real (Reed 1952), became one traditional place in conflict at that time. Local warriors were trained in traditional martial arts and fighting techniques, including the use of sling stones and human bone pointed spears (Figure 5.5), but not the art of European warfare. Consequently, Chamorro warriors soon found themselves unable to repel newly arrived Spanish soldiers with Sergeant Major Joseph de Quiroga y Losada in 1679 CE, some in armour and perhaps mounted on a few horses, many armed with muskets or swords (Figure 5.6). The scale of combat involving civilians as targets and seizure of high-status warriors for public execution must have also been unnerving, accustomed as Chamorro were to a negotiated resolution after minimal casualties.
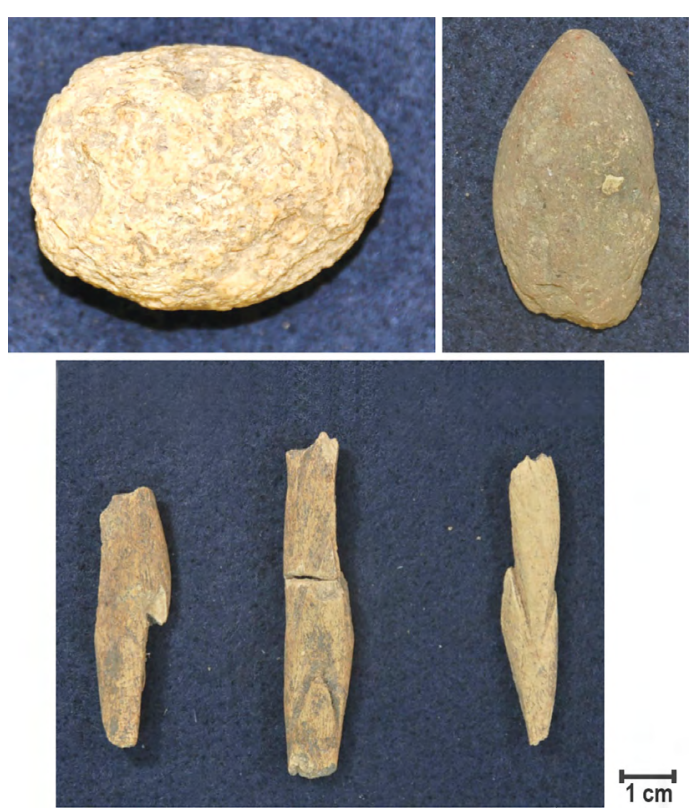

Figure 5.5. Limestone and volcanic sling stones and human bone spearpoints.

Source: Andrea Jalandoni.

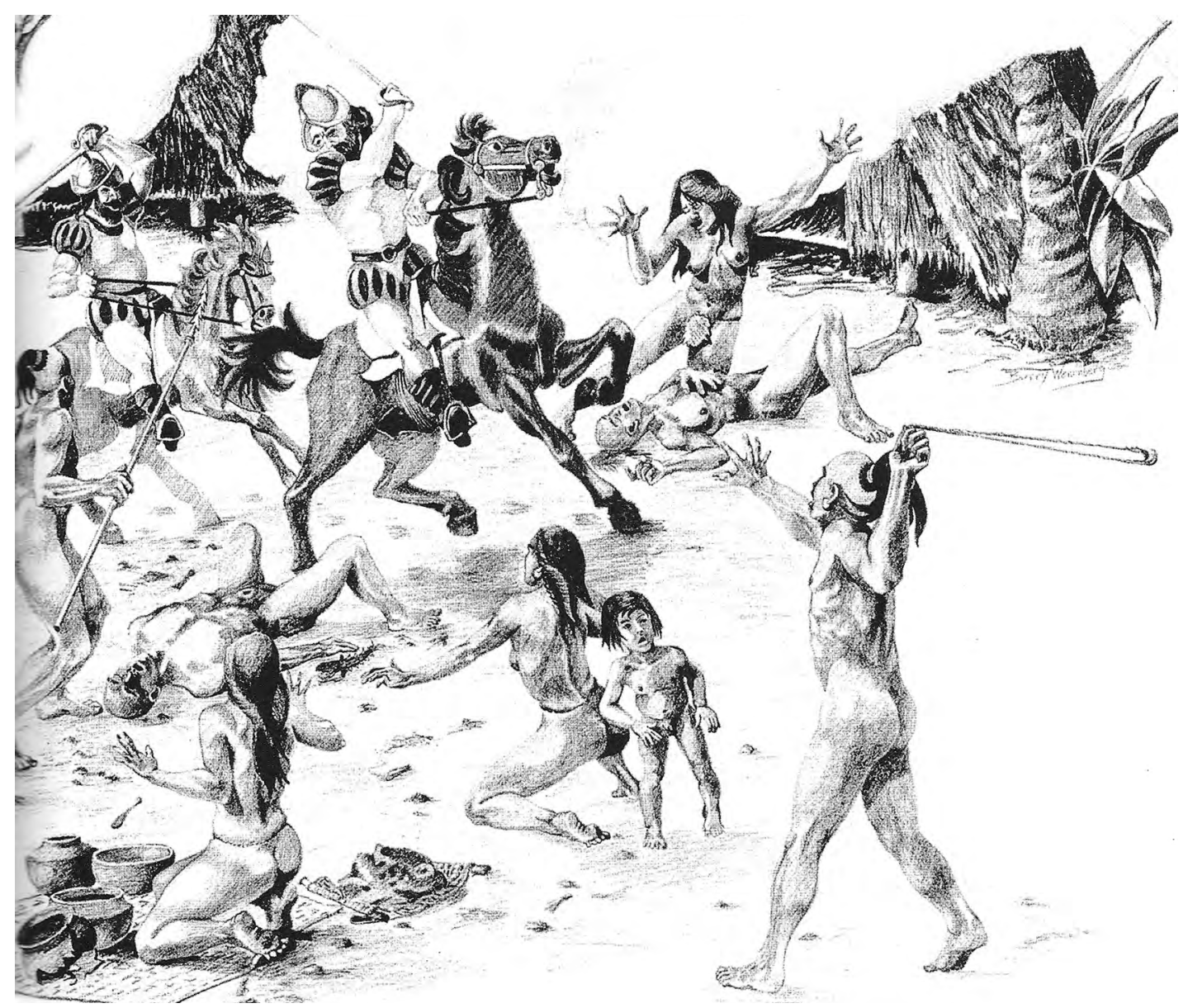

Figure 5.6. Reconstruction of a Spanish raid on a Chamorro Village, c. $1680 \mathrm{CE}$.

Source: Don Farrell (2011:169). 
In the same year, an enclave of resistors to Spanish mandates had gathered at the relatively inaccessible village and water cave of Hanum below the cliffs on the north-eastern side of Guam. After the Spanish attempt at a sunrise surprise was foiled by lookouts, the troops divided into four groups to cover native escape or resupply upon razing the village. García (2004:492) describes the results of this rout:

The houses, with everything that could not be used by the victors, were consumed in flames. Fifty boats that were taken as the spoils of war were given to the friendly natives. Those they did not want were burned. The remaining booty was shared among the soldiers and the natives, except for the rice, which was kept for the general food supply and was taken by boat to Agadña.

During this same campaign, after Brother Diaz was killed and the first church was burned, the village of Ritidian was soon abandoned, presumably expecting swift Spanish retribution. The village was later resettled briefly, but the entire population was soon removed by Spanish soldiers to southern villages on Guam. The area was only repopulated as a rural ranch setting in the 1800s CE, when small ranches or lanchos and a limited population lived off subsistence farming and fishing or reef collecting. It is probable former Ritidian residents attended mass in Hagånna or a nearby rural church on Sundays, but returned to their lanchos during the week, thus avoiding potential conflict with civilian and Spanish administration and clergy in Hagåtña. The implementation of the lancho system (Bayman et al. 2020) was undoubtedly encouraged by later colonial governments and clergy as a means to collect produce and wood from agricultural farms and nearby forests during the week, while indoctrinating the children in religious schools without the possible conflict of parental supervision.

Skeletal evidence of violence in the Mariana Islands during the early Spanish Colonial Period (1668-1720 CE) is difficult to date, in part because such apostate individuals would likely have been buried in a contested ceremony with failure to convert to Christian burial customs. One Chamorro male aged 50 excavated on the island of Tinian and given the name Taotao Tagga was found to have a healed wound to the face and cheek bone, likely inflicted by a metal weapon while the individual was in his 20 s or 30s. 'The force of the blow was so strong that the cheek bone was displaced downward and outward where it meets the upper jaw' (Heathcote 2006:5). The date of his burial was postulated to have occurred well before $1695 \mathrm{CE}$ when Chamorro were driven from the Aguijan stronghold (see Figure 5.2) to resettlement on Guam.

At the site of Achugao on the west coast of Saipan, fragments of a small metal flush loop bell were found just above the left side of the pelvis on a Latte Period burial, apparently having been attached to something around the waist (Butler 1995:345).

The author argues that this particular specimen likely dates between the wreck of the Nuestra Señora de la Concepción on the south coast of Saipan in 1638 and the end of the Chamorro settlement of Saipan around CE 1730. (Dixon et al. 2017:201)

At Laulau House A on the east coast of Saipan, an iron spear point, a nail and an iron knife blade fragment were found beneath rocks packed around a latte stone (Spoehr 1957:167), 'suggesting a post-Contact ending date to the Latte Period occupation' (Dixon et al. 2017:201) at this site and perhaps at Achugao. No burial evidence of conflict was noted in either case.

\section{First American administration conflict: 1898-1941 CE}

At the end of the Spanish-American War in 1898 CE, Guam was ceded by Spain to the US Government with little conflict locally, but Guam did not become a US territory until $1950 \mathrm{CE}$. Between 1898 and $1941 \mathrm{CE}$, Guam served as a coaling and fuelling station for naval ships and other vessels, as the site of the trans-Pacific cable station, as the base for a strategic naval radio 
station, and as a landing place for the Pan-American trans-Pacific air clippers flying between San Francisco and Hong Kong. Despite being surrounded by Japanese-controlled islands, the United States did little in terms of military defence development (Peattie 1988), under the terms of their agreement with other colonial powers in the Pacific after World War I.

During the early twentieth century in northern Guam, many of the inland inhabitants were involved in the commercial production of dry coconut meat for the copra export market, as well as subsistence farming at small lanchos in the jungle (Dixon et al. 2016). This patchy quilt-like pattern of small farms and surrounding forests remained during the first half of American rule. Some grazing of cattle and growing cash crops also occurred in clearings along newly widened roads on the northern plateau prior to World War II.

By $1940 \mathrm{CE}$, an official census recorded a total of 80 farms in northern Guam, each averaging 7.1 hectares (Hunter-Anderson and Moore 2003), far more land than was needed to support one family on home gardening alone. Recent archaeological survey of these plateau areas within Andersen Air Force Base has recorded post-World War II refuse at several pockets of arable soil with coconut trees of considerable age near Pott's Junction, likely reflecting a better postwar economy for Chamorro farmers.

\section{World War II and Cold War conflict: 1941 CE-present}

Global conflict again manifested itself on the island in the mid-twentieth century with World War II and then the Cold War conflict, arguably still the prevailing paradigm today. There is no record of Japanese landings at Ritidian during their 1941 invasion of Guam, although Chamorro policemen from Saipan were landed at night to help the Japanese coordinate the takeover of civilian populations (Rogers 1995). One encampment of Japanese troops was placed at Pott's Junction to control access of the public, and one fortified anti-aircraft position was discovered in the jungle nearby (Dixon et al. 2016) to defend air space during the eventual invasion. PreWorld War II American fortification and then abandonment of Ritidian Point is also suggested by a 1944 CE Japanese map of the general area that shows a 'lookout' and 'remains of a battery' located at the end of the pre-existing vehicle road, probably replaced by a defensive overlook at the point by the Japanese.

At the end of combat with American troops to retake the island in August $1944 \mathrm{CE}$, small groups of Japanese stragglers sought refuge in the cliffs at the base of Ritidian Point, and limited evidence was found of abandoned weapons (Kurashina et al. 1990) and modified rock shelters for defence as stragglers rejoined ranks in Tarague until the war's end. The barrel and firing mechanism of a Japanese military rifle found in the Guam National Wildlife Reserve (Kurashina et al. 1990) indicate that armed stragglers likely passed along the coast at the end of the war, perhaps along the 'mule path circa $1 \mathrm{~m}$ wide' depicted on the 1944 CE Japanese map (Dixon et al. 2011b).

When Guam was recaptured in 1944 CE, the US military followed through with a massive military build-up, transforming Guam into an important communications, repair, resupply and air support centre for the remaining battles of the Pacific War. The construction of Northwest Field on the plateau (Figure 5.7) created one of several American air bases built to launch B-29 bombing raids on Japan and military targets across the western Pacific (Dixon et al. 2016). By the end of July $1945 \mathrm{CE}$, almost 80 per cent of the south taxiway and parking area was complete, but by $1948 \mathrm{CE}$, activity at Northwest Field had decelerated as a victim of shifting postwar missions. Northwest Field was vacated in the spring of $1949 \mathrm{CE}$, but its housing area remained in use until 1962 CE. In April 1975 CE, at the end of the Vietnam War, the base received almost 40000 refugees and processed another 109000 for onward transportation to the United States as part of Operation New Life. 


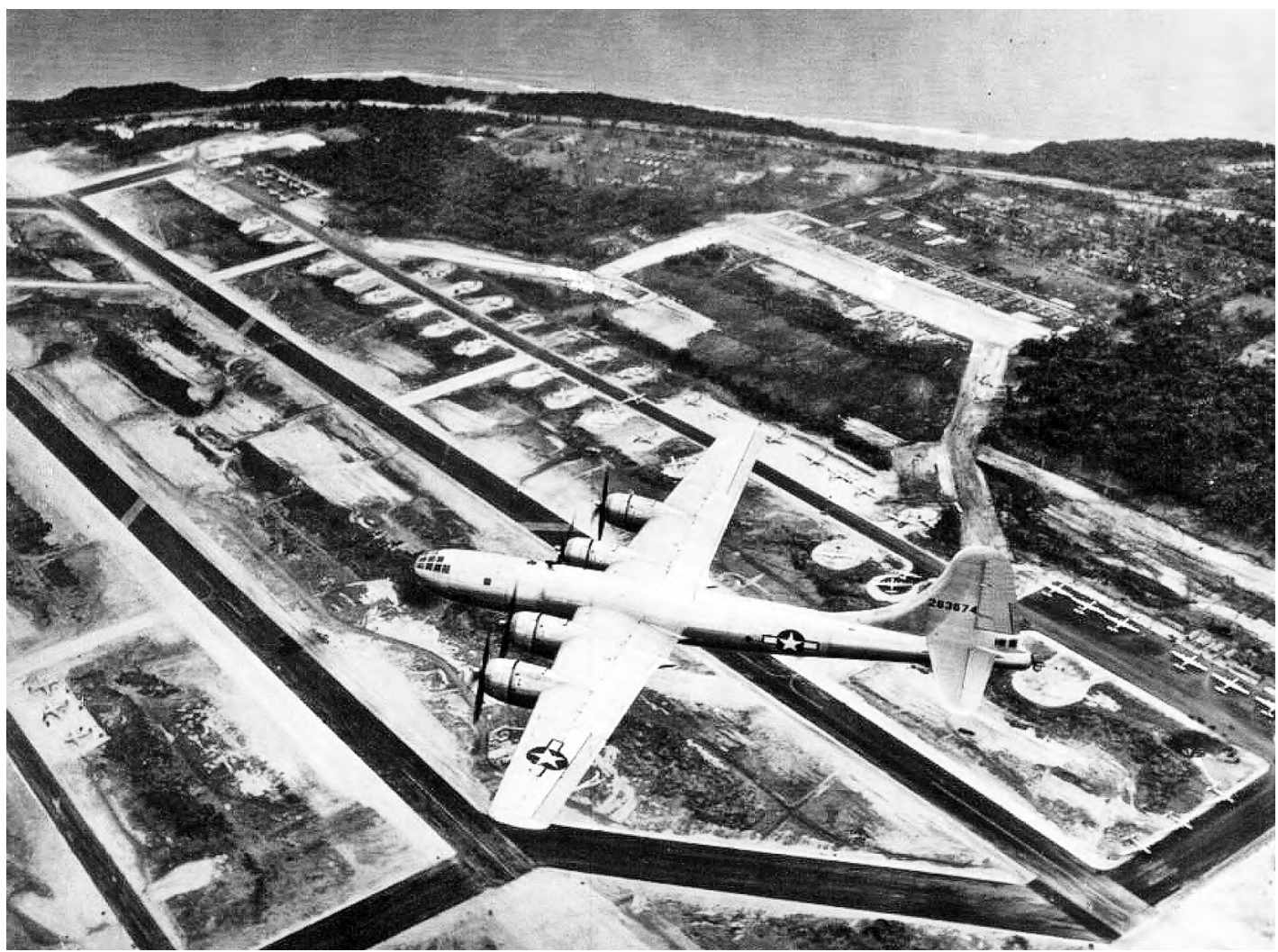

Figure 5.7. B-29 over Northwest Field, Guam c. 1945.

Source: Judith Amesbury (2019:33).

Not long thereafter, Ritidian once again became a flashpoint of sociopolitical conflict throughout the 1960s and 1980s CE when the US Navy denied access to Chamorro owners and residents while clearing and developing infrastructure for a classified facility on the previous site of a latte set and the former Casa Real (Kurashina et al. 1990). The US Navy Sound Surveillance System or SOSUS was invented as a long-range, early warning listening system. This Cold War facility, when abandoned in the late 1980s, was deeded to the US Fish and Wildlife Service as part of the Ritidian Unit of the Guam National Wildlife Refuge (Jalandoni 2011). Former landowners were not allowed to return to their coastal property and access from the plateau above was curtailed at Pott's Junction until 1993 CE while construction of military support facilities proceeded. Conflict arose as fences were then erected and public hunting restricted, while access to the Guam National Wildlife Refuge is only allowed by appointment today.

\section{Conclusions and continuations}

Construction of various projects to support the US Department of Defense mission continues, including a live fire training range for the US Marines on the plateau above Ritidian. This has raised concern that the coastal setting will be closed from visitation within a live fire safety exclusion zone for much of the year, with growing resistance to such plans by many Chamorro and other island residents and members of the Government of Guam. Also surfacing are accounts of exposure to Agent Orange, stored and used by US veterans on Guam in the 1970s during the Vietnam War (Kime 2020) and the effects of atomic fallout on civilians from nuclear testing in Micronesia during the Cold War (National Research Council 2005:Appendix C). In 2020 CE, with new restrictions on Guam residents due to the COVID-19 pandemic, conflict over public access to Ritidian is stirring. 
As can be seen from this Mariana Islands-focused reconstruction of native and resident conflict with Spanish, German, Japanese and American culture contact in Micronesia, resistance and accommodation to colonialisation has taken many forms, from armed uprising to political action and civil disobedience. So, while not constructed as such during the Latte Period, the village site of Ritidian on Guam has indeed been a 'traditional place of conflict' over several centuries. Perhaps too, community and international dialogue generated by such confrontation will reflect a positive and healing sense of the Chamorro place name of Litekyan or the 'stirring place' (Carson 2018), situated both literally and figuratively in this ever-changing sea of islands.

\section{Acknowledgements}

The authors would like to thank the following people for their support, including the generous invitation to contribute to Archaeological perspectives on conflict and warfare in Australia and the Pacific, and the opportunity to participate in the Australian Archaeological Association Annual Conference on the Gold Coast, 10-13 December 2019, 'Disrupting paradise: The archaeology of the driest inhabited continent on Earth'.

Dr Mirani Litster, The Australian National University; Prof. Geoffrey Clark, The Australian National University; Dr Sven Ouzman, The University of Western Australia; Dr Daryl Wesley, Flinders University; Dr Kelly Marsh, Guam Legislator; Dr Michael Carson, University of Guam; Dr William Jeffries, University of Guam; Dr David Atienza, University of Guam; Dr Patrick Nunn, University of the Sunshine Coast; Dr John Peterson, University of San Carlos; Dr Jim Bayman, University of Hawai' $i$ at Mānoa; Don Farrell, Tinian; Scott Russell, CNMI Humanities Council; Judy Amesbury, Micronesian Archaeological Research Services; David DeFant, SEARCH Inc.; Richard Schaefer, IA LLC; Cherie Walth, SWCA Environmental Consultants; Dr Michael Dega, Scientific Consultant Services; Dr David Tuggle, retired; Aja Reyes, CardnoGS; and the Chamorro archaeologists and University of Guam students who shared our research as friends and colleagues with staff at the Ritidian Unit of the Guam National Wildlife Refuge. Special thanks to Guampedia for their continued support.

The authors bear the responsibility for errors in fact or interpretation and for those supporters not mentioned here. Please note that this research does not represent the opinion or the policy of the US Fish and Wildlife Service or the US Navy and their subcontractors.

\section{References}

Amesbury, J. 2019. Archaeology on the northern plateau of Guam. Booklet prepared for the US Navy by Cardno-GS, Guam.

Bayman, J., M. Carson, J. Peterson, H. Kurashina and D. Doig 2010. University of Guam and University of Hawai i Archaeological Field School at the Guam National Wildlife Refuge, Ritidian Unit, Territory of Guam: The $2009 \& 2008$ seasons. Unpublished report prepared for Guam National Wildlife Refuge.

Bayman, J., H. Kurashina, M.T. Carson, J.A. Peterson, D. Doig et al. 2012. Latte household economic organization at Ritidian, Guam National Wildlife Refuge, Mariana Islands. Micronesica 42(1/2):258273.

Bayman, J., B. Dixon, S. Monton-Subias and N. Moragas Segura 2020. Colonial surveillance, lancho, and the perpetuation of intangible cultural heritage in Guam, Mariana Islands. In C. Beaule and J. Douglass (eds), The global Spanish empire: Five hundred years of place making and pluralism, pp. 222-241. University of Arizona Press, Tucson. doi.org/10.2307/j.ctv105bb41.14. 
Butler, B. 1992. An archaeological survey of Aguiguan (Aguijan) Northern Mariana Islands. Micronesian Archaeological Survey Report Number 29. Division of Historic Preservation, Department of Community and Cultural Affairs, Saipan.

Butler, B. 1995. Archaeological investigations in the Achugao and Matansa areas of Saipan, Mariana Islands. Micronesian Archaeological Survey Report Number 30. Division of Historic Preservation, Department of Community and Cultural Affairs, Saipan.

Carson, M. 2010. Radiocarbon chronology with marine reservoir correction for the Ritidian archaeological site, Northern Guam. Radiocarbon 52(4):1627-1638. doi.org/10.1017/s0033822200056356.

Carson, M. 2012. Evolution of an Austronesian landscape: The Ritidian site in Guam. Journal of Austronesian Studies 3(1):55-86.

Carson, M. 2014. First settlement of remote Oceania: Earliest sites in the Mariana Islands. Springer, New York. doi.org/10.1007/978-3-319-01047-2.

Carson, M. 2017. Cultural spaces inside and outside caves: A study in Guam, Western Micronesia. Antiquity 91(356):421-441. doi.org/10.15184/aqy.2016.233.

Carson, M. 2018. Lina'la' portraits of life at Litekyan. Micronesian Area Research Center, University of Guam Press, Guam.

Coomans, P. 1995. History of the Mariana Island Mission for the 1667-1673 period. In R. Lévesque (ed.), History of Micronesia: A collection of source documents. Volume 3: First real contact. Document 1673L1. Lévesque Publications, Quebec.

Craib, J. 1986. Casas de los Antiguos: Social differentiation in protohistoric Chamorro society, Mariana Islands. Unpublished PhD thesis. University of Sydney, Australia.

Dasmarinas, G.P. 1595. Boxer codex. Record and manuscript at the Lilly Library, Indiana University, Bloomington.

DeFant, D. 2008. Early human burials from the Naton Beach site, Tumon Bay, Island of Guam, Mariana Islands. Journal of Island and Coastal Archaeology 3(1):149-153. doi.org/10.1080/15564890801990789.

Dega, M., D. Perzinski and J. Ferrugia 2017. The Latte village of Garapan: Archaeological data recovery, Saipan Commonwealth of the Northern Mariana Islands. Prepared for Imperial Pacific International (CNMI), LLC, Scientific Consulting Services, Inc., Honolulu.

Dickinson, W. 2000. Hydro-isostatic and tectonic influences on emergent Holocene paleoshorelines in the Mariana Islands, Western Pacific Ocean. Journal of Coastal Research 16:735-746.

Dickinson, W. 2001. Paleoshoreline record of relative Holocene sea levels on Pacific Islands. Earth Science Review 55:191-234. doi.org/10.1016/s0012-8252(01)00063-0.

Dixon, B. 2011. Ancient CHamoru warfare. Guampedia, last modified 24 April 2021. www.guampedia. com/ancient-guam-warfare.

Dixon, B. and M. Dega In press. Placing the early pre-Latte period site of San Roque on Saipan in its broader context: 1500-1100 B.C. In M. Napolitano and S. Fitzpatrick (eds), When the wild winds blow: Micronesia colonization in Pacific context. Society for American Archaeology, San Francisco.

Dixon, B. and L. Gilda 2011. A comparison of an inland Latte Period community to coastal settlement patterns observed on southern Guam. People and Culture of Oceania 27:65-86.

Dixon, B. and A. Jalandoni 2019. Traditional places in conflict: Ritidian, Guam. Paper presented at 'Disrupting paradise: The archaeology of the driest inhabited continent on Earth', the Australian Archaeological Association Annual Conference 2019, Gold Coast, 10-13 December. 
Dixon, B. and R. Schaefer 2014. Reconstructing cultural landscapes for the Latte Period settlement of Ritidian: A hypothetical model in Northern Guam. In M. Carson (ed.), Guam's hidden gem: Archaeological and historical studies at Ritidian, pp. 64-73. British Archaeological Reports International Series, Oxford. doi.org/10.30861/9781407313054.

Dixon, B., T. Mangieri, E. McDowell, K. Paraso and T. Reith 2006. Latte Period domestic household activities and disposal patterns on the Micronesian island of Tinian, CNMI. Micronesica 39(1):55-71.

Dixon, B., H. Bartow, J. Coil, W. Dickinson, G. Murakami and J. Ward 2011a. Recognizing inland expansion of Latte Period agriculture from multi-disciplinary data on Tinian, Commonwealth of the Northern Mariana Islands. Journal of Island and Coastal Archaeology 6(3):375-397. doi.org/10.1080/ 15564894.2010 .521539 .

Dixon, B., R. Schaefer and T. McCurdy 2011b. Level 1 archaeological reconnaissance of 800 acres within selected properties on Andersen Air Force Base, Guam. Volume 1: Narrative. Cardno TEC Inc., Guam for SEARCH Inc., Honolulu.

Dixon, B., T. McCurdy, D. Welch, R. Jones and I. Nelson 2016. Archaeological data recovery in support of construction for MILCON P-175, Andersen Air Force Base, Yigo, Guam. Cardno TEC Inc., Guam.

Dixon, B., A. Jalandoni and C. Craft 2017. The archaeological remains of early modern Spanish colonialism on Guam and their implications. In M. Cruz Berrocal and C. Tsang (eds), Historical archaeology of early modern colonialism in Asia-Pacific: The southwest Pacific and Oceanian regions, Volume 1, pp. 195-218. University Press of Florida, Gainesville. doi.org/10.2307/j.ctvx07b3c.14.

Dixon, B., C. Walth, K. Mowrer and D. Welch 2019. Afetna Point, Saipan: Archaeological investigations of a Latte Period village and historic context in the Commonwealth of the Northern Mariana Islands. ArchaeoPress Access Archaeology, Oxford.

Egami, T. and F. Saito 1973. Archaeological excavation on Pagan in the Mariana Islands. Journal of the Anthropological Society of Nippon 81(3):203-226. doi.org/10.1537/ase1911.81.203.

Farrell, D. 2011. History of the Mariana Islands to partition. Public school system, Commonwealth of the Northern Mariana Islands, Saipan.

Farrell, D. 2012. Tinian: A brief history. Pacific Historic Parks, Honolulu.

Flexner, J. 2014. Historical archaeology, contact, and colonialism in Oceania. Journal of Archaeological Research 22:43-87. doi.org/10.1007/s10814-013-9067-z.

García, F. 2004 (1683). The life and martyrdom of the venerable Father Diego Luis De San Vitores, S.J. MARC Monograph Series No. 3. University of Guam Press, Guam.

Heathcote, G. 2006. Taotao tagga': Glimpses of his life history, recorded in his skeleton. Paper Number 3, Non-Technical Report Series. University of Guam, Mangilao.

Hezel, F. 2015. When cultures clash: Revisiting the 'Spanish-Chamorro Wars'. Northern Marianas Humanities Council, Saipan.

Hezel, F. 2016. German rule in Micronesia. FSM Historic Preservation Office, Pohnpei.

Hezel, F. and M. Driver 1988. From conquest to colonization: Spain in the Mariana Islands 1690-1740. The Journal of Pacific History 23(2):137-155. doi.org/10.1080/00223348808572585.

Hornbostel, H. 1924-25. Unpublished notes and catalogs. Library Department, Bernice P. Bishop Museum, Honolulu.

Hunter-Anderson, R. and D. Moore 2003. Cultural resources Snake Barrier concept, Andersen Air Force Base, Guam. Prepared for Innovative Technical Solutions, Inc. Walnut Creek, California by Micronesian Archaeological Research Services, Guam. 
Jalandoni, A. 2011. The Casa Real site in Ritidian, Northern Guam: A historical context. Philippine Quarterly of Culture and Society 39:27-53.

Jalandoni, A. and J. Peterson 2013. Conflict at contact: Late 17th century Spanish missions and la Reducción in Northern Guam. Paper delivered at Society for American Archaeology Annual Meeting 3-7 April 2013, Honolulu, Hawaii.

Kime, P. 2020. Report claims Vietnam-era veterans were exposed to Agent Orange on Guam. Military. com, 11 May. www.military.com/daily-news/2020/05/11/report-claims-vietnam-era-veterans-wereexposed-agent-orange-guam.html.

Kurashina, H., J.A. Simons, J.A. Toenjes, J. Allen, S.S. Amesbury et al. (eds) 1990. Archaeological investigations at the Naval Facility (NAVFAC) Ritidian Point, Guam, Mariana Islands. Report prepared for United States Department of the Navy. Micronesian Area Research Center, University of Guam, Mangilao.

Liston, J. 2009. Cultural chronology of earthworks in Palau, Western Micronesia. Archaeology of Oceania 44:56-73. doi.org/10.1002/j.1834-4453.2009.tb00047.x.

Liston, J. 2014. Ritual use of Palau's monumental earthworks and leadership strategies. In H. MartinssonWallin and T. Thomas (eds), Monuments and people in the Pacific, pp. 101-128. Studies in Global Archaeology No. 20. Uppsala University, Sweden.

Liston, J. and H.D. Tuggle 2006. Prehistoric warfare in Palau. In E. Arkush and M.W. Allen (eds), The archaeology of warfare: Prehistories of raiding and conquest, pp. 148-183. University Press of Florida, Florida.

Morgan, W. 1988. Prehistoric architecture in Micronesia. University of Texas Press, Texas.

National Research Council 2005. Assessment of the scientific information for the radiation exposure screening and education program. The National Academies Press, Washington DC. www.nap.edu/ catalog/11279/assessment-of-the-scientific-information-for-the-radiation-exposure-screening-andeducation-program. doi.org/10.17226/11279.

Nunn, P. 2007. Climate, environment and society in the Pacific during the last millennium. Developments in Earth and Environmental Sciences 6. Elsevier, Amsterdam. doi.org/10.1016/s1571-9197(07) 06001-6.

Nunn, P., R. Hunter-Anderson, M. Carson, F. Thomas, S. Ulm and M. Rowland 2007. Times of plenty, times of less: Last-millennium societal disruption in the Pacific Basin. Human Ecology 35(4):345-401. doi.org/10.1007/s10745-006-9090-5.

Peattie, M. 1988. Nanyo the rise and fall of the Japanese in Micronesia 1885-1945. University of Hawai' $\mathrm{i}$ Press, Honolulu.

Pigafetta, A. 1992. Magellan's voyage-primary account by Pigafetta-the Italian manuscript. In R. Lévesque (ed.), History of Micronesia: A collection of source documents. Volume 1: European discovery. Document 1521B1. Lévesque Publications, Quebec.

Pobre, J. 1992. The story of Fray Juan Pobre's stay at Rota in the Ladrone islands in 1602. In R. Lévesque (ed.), History of Micronesia: A collection of source documents. Volume 3: First real contact. Document 1602A. Lévesque Publications, Quebec.

Rainbird, P. 2004. The archaeology of Micronesia. Cambridge University Press, Cambridge.

Reed, E. 1952. General report on archaeology and history of Guam. Report prepared for Governor of Guam. US National Park Service, Washington, DC. 
Reinman, F. 1977. An archaeological survey and preliminary test excavations on the Island of Guam, Mariana Islands, 1965-1966. Miscellaneous Publications No. 1. Micronesian Area Research Center, University of Guam, Mangilao.

Rogers, R. 1995. Destiny's landfall: A history of Guam. University of Hawai'i Press, Honolulu.

Russell, S. 1984. From Arabawal to ashes: A brief history of Garapan Village, 1818 to 1945. Micronesian Archaeological Survey Report Number 19. Division of Historic Preservation, Saipan.

Russell, S. 1998. Tiempon I Manomofo 'ona: Ancient Chamorro culture and history of the Northern Marianas Islands. Micronesian Archaeological Survey Report 32. Division of Historic Preservation, Saipan.

Shell, R. 1999. The Marianas population decline: 17th century estimates. The Journal of Pacific History 34(3):291-305. doi.org/10.1080/00223349908572914.

Spoehr, A. 1957. Marianas prehistory. Archaeological survey and excavations on Saipan, Tinian and Rota. Fieldiana Anthropology 48. Chicago Natural History Museum, Chicago. doi.org/10.5962/bhl. title.3552.

Thompson, L. 1932. Archaeology of the Marianas Islands. Bernice P. Bishop Museum Bulletin 100. Bishop Museum Press, Honolulu.

Thompson, L. 1940. The function of Latte in the Marianas. Journal of the Polynesian Society 49:447-465.

Tomonari-Tuggle, M., T. Rieth, D. Tuggle, M. Bell and D. Knecht 2018. A synthesis of archaeological inventory and evaluation efforts on the island of Guam. Volume II: AD 1521-1950. Prepared by International Archaeology LLC, Honolulu.

Underwood, J. 1973. Population history of Guam: Context of microevolution. Micronesica 9(1):11-44.

Velarde, P.M. 1987. The 'Reduccion' of the Islands of the Ladrones, the discovery of the islands of the Palaos and other happenings. Translated by E.F. Plaza and republished as Working Paper No. 51. Micronesian Area Research Center, University of Guam, Mangilao.

Vilar, M., F. Camacho, D. Santos, K. Lum and T. Schurr 2016. The origins and genetic distinctiveness of the Chamorros: A bi-parental analysis. University of Guam Presidential Lecture Series, 26 January 2016, Mangilao.

Walth, C. 2016. Archaeological investigations at the Naton Beach site, Tumon, Guam. Volume II: The osteological analysis of human remains. Prepared for Guam Hotel Okura, SWCA Environmental Consultants, Albuquerque.

York, R. and G. York 2014. Slings and slingstones: The forgotten weapons of Oceania and the Americas. Kent State University Press, Kent. 
This text is taken from Archaeological Perspectives on Conflict and Warfare in Australia and the Pacific, edited by Geoffrey Clark and Mirani Litster, published 2022 by ANU Press, The Australian National University, Canberra, Australia.

doi.org/10.22459/TA54.2021.05 